\title{
Suitability Analysis for Sanitary Landfill Site in the Province of Ifugao, Philippines
}

\author{
Mark Joseph J. Buncag, MSc ${ }^{\# 1}$, Lea Mari Santos, MSc ${ }^{* 2}$, Angelica Magpantay, MSc ${ }^{\# 3}$ \\ ${ }^{\#}$ Faculty, Palawan State University San Vicente Campus \\ "Ph.D in Environmental Science Student, SESAM, University of the Philippines Los Baños (UPLB)

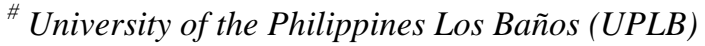

\begin{abstract}
Solid wastes generation is an alarming contemporary environmental issue. As part of national strategies in solid wastes management as stipulated in RA 9003 otherwise known as the Ecological Solid Wastes Management Act of 2001 is the establishment of sanitary landfills by the local government units. This study aims to assess and identify key suitable sites in the province of Ifugao in accordance with the sanitary landfill siting area requirement and generate sanitary landfill suitability map. This study utilized weighted overlay analysis of required maps based on landfill siting area requirement using ArcMap GIS software licensed to UPLB.
\end{abstract}

Based from the generated sanitary landfill suitability map, there are areas fall on restricted, low, moderate, high, and very high suitability for sanitary landfill site in which large areas of Ifugao province fall on restricted zone. Only three municipalities have land areas that fall under the category of very high suitability, namely Alfonso Lista (1,287 ha), Aguinaldo (9 ha), and Hungduan (2 ha). Municipality of Alfonso Lista has the largest area fall on high suitability. Also, the top three municipalities in terms of land area under high suitability are Alfonso Lista (14, 232 ha), Aguinaldo (11, 907 ha), and Lagawe (5, 817 ha).

Keywords: sanitary landfill, suitability map, sanitary landfill siting area requirement, Ifugao province

\section{INTRODUCTION}

Solid wastes generation is an alarming contemporary environment issues that the Philippines is facing in which the trend is increasing caused by the increase of people, development of living standard, fast financial growth, and industrialization particularly in town areas (Senate Economic Planning Office, 2017). The computed solid waste generation in the country in 2012 is 37,427.46 tons per day and steadily increase until 2016 with 40,087.45 tons per day (NSWMC, 2015). Majority of the solid wastes generated were from residential (57\%) then commercial (27\%) followed by institutional (12\%) and industrial (4\%) (NSWMC, 2017).

As part of national strategies in solid wastes management as stipulated in RA 9003 otherwise known as the Ecological Solid Wastes Management Act of 2001 is the establishment of sanitary landfills by the local government units (LGU). Based from NSWMC (2015), there are 86 existing sanitary landfills in the country that caters the increasing generated solid wastes and these existing sanitary landfills has its own capacity. In this case, establishment of sanitary landfills and expansion/improvement of existing sanitary landfills in local government units is really needed and mandated in RA 9003 to properly manage the solid wastes generated by different sources.

Lack of proper wastes management causes human health problems like diarrhea, helminthiasis, typhoid/paratyphoid, cholera, and hepatitis A that may cause complications and death. Also, wildlife and marine organisms can be negatively affected by mismanaged wastes. These diseases can be mitigated through wastes management like establishment of sanitary landfill.

Establishment of sanitary landfill is one of the strategies to manage solid wastes in order to mitigate health-related problems and impacts on wildlife and marine organisms. However, there are criteria to be considered in identifying suitable sites for the establishment of sanitary landfill based from the guidelines of 
DENR through DAO 1998-50. These criteria include land use, road, slope, river, ground water, key biodiversity/protected areas, land cover, ground water, soil, erosion susceptibility, cultural sites, settlements/built-up areas and faults.

Ifugao is one of the provinces in Cordillera Administrative Region (CAR) and can be found in a mountainous area. This province needs a sanitary landfill that will cater the wastes generated by households, tourists, and other institutions in the entire province. So, this study will identify areas that are suitable for establishing sanitary landfills based from the guideline of the government.

This study aimed to determine suitable sanitary landfill site/s in the province of Ifugao considering the criteria based from guidelines of DENR through DAO 1998-50.

\section{A. Study Area}

\section{MATERIALS AND METHODS}

This study mainly focused on province of Ifugao, Philippines in determining the suitable sanitary landfill sites covering its all municipalities. It has 11 municipalities and 175 barangays. Ifugao is located at the foot of the Cordillera Mountain Ranges. It is bounded on the west by Benguet, on the south by Nueva Vizcaya, on the east by Isabela and on the north by Mt. Province. It is generally located at 1650'0' ' N and 12110'0 E. It has a land area total of 2,517.78 sq. km. spread over its 11 municipalities. The main city in terms of land area is Aguinaldo with 454.51 sq. $\mathrm{km}$. or $18.05 \%$ of the total regional land area while the fewest is Hingyon with 114.56 sq. km. or $4.55 \%$.

The research area showed in Figure 1 covering all 11 municipalities of Ifugao province.

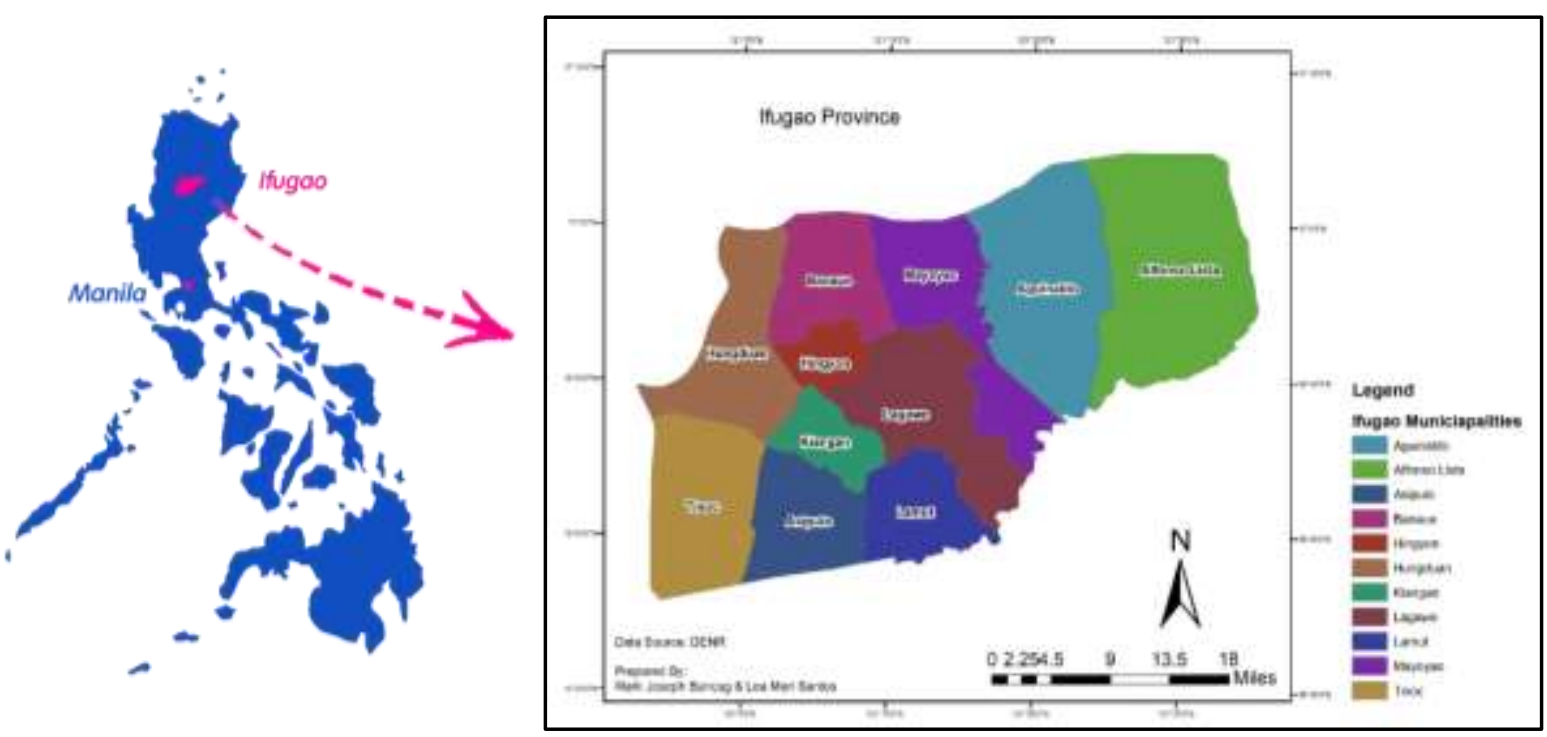

Figure 1. Provincial Map of Ifugao 


\section{B. Conceptual Framework}

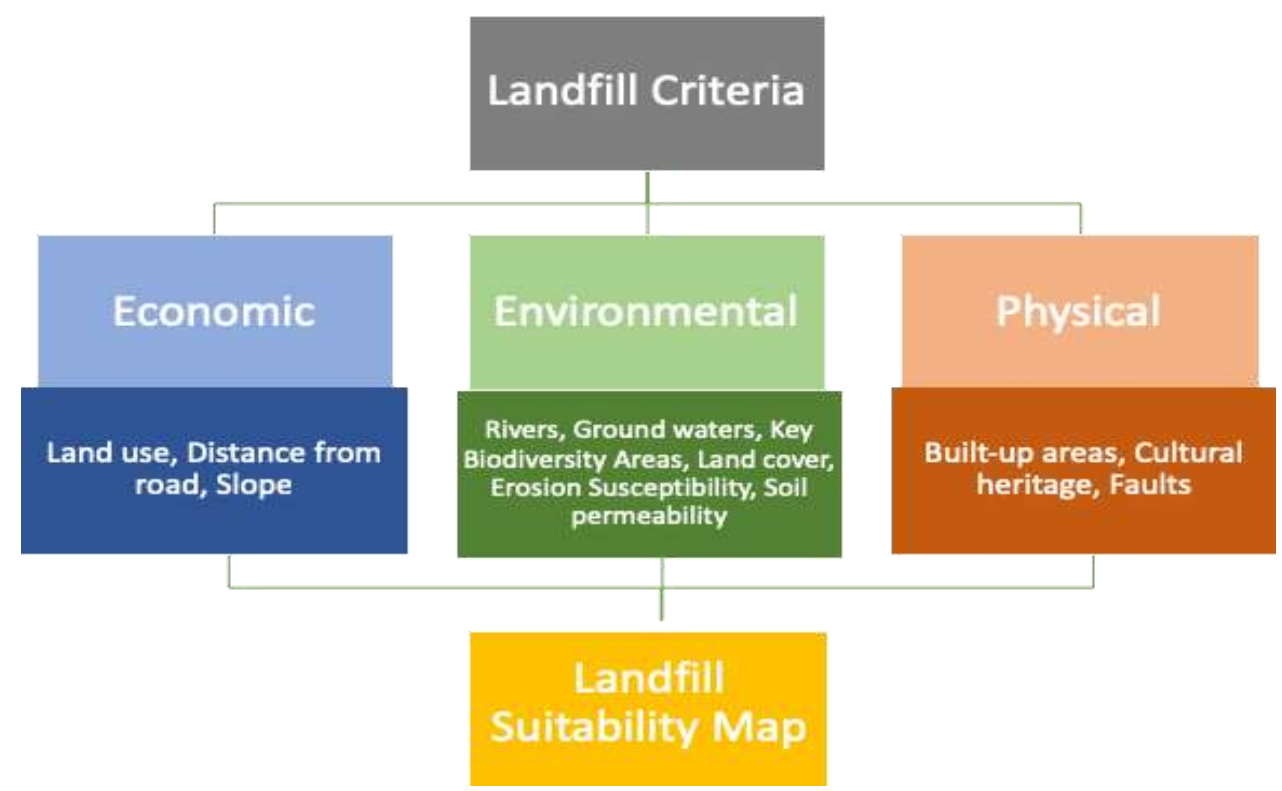

Figure 2. Conceptual Framework of the Study

\section{Landfill Site Selection Criteria}

In this study, guidelines from Department of Environment and Natural Resources (DENR) and Housing and Land Use Regulatory Board (HLURB) was utilized as criteria for landfill site selection (see Table $1)$.

\section{Secondary Data Collection}

Available secondary data in shapefile format requested from DENR was utilized in this study for spatial overlay analysis. DEM data was downloaded from USGS Earth Explorer portal to generate slope map of the study area.

Table 1. List of all the Data Requirements for Landfill Suitability Mapping

\begin{tabular}{|c|c|}
\hline Criteria & Dataset Requirement* \\
\hline Economic & \\
\hline Land use & Existing land use \\
\hline Distance from roads & Road Network \\
\hline Slope & $\begin{array}{l}\text { ASTER DEM (30m resolution) } \\
\text { (source: USGS Earth Explorer) }\end{array}$ \\
\hline Environmental & \\
\hline Distance from surface waters/rivers & Surface water/River Network \\
\hline Ground waters & Groundwater map \\
\hline Distance from Key Biodiversity /Protected Areas & Biodiversity /Protected Areas Map \\
\hline Land Cover & Land cover map \\
\hline Soil Erosion & Erosion Map \\
\hline Soil permeability & Soil map \\
\hline
\end{tabular}




\begin{tabular}{|l|l|}
\hline Physical & \\
\hline Distance from Built-up areas/ settlements & Built-up/settlement sites \\
\hline Distance from cultural heritage & POIs of cultural sites \\
\hline Distance to Faults(Seismic Conditions) & Active Faults \\
\hline
\end{tabular}

*Data Source: DENR, except Slope map-generated from DEM data downloaded from USGS Earth Explorer portal

Table 2. Weight Assignments

\begin{tabular}{|c|c|c|c|}
\hline Main Criteria & Weight & Sub-Criteria & Weight \\
\hline \multirow[t]{3}{*}{ Economic } & \multirow[t]{3}{*}{0.21} & Land Use & 0.54 \\
\hline & & Distance from roads & 0.30 \\
\hline & & Slope & 0.16 \\
\hline \multirow[t]{6}{*}{ Environmental } & \multirow[t]{6}{*}{0.55} & Distance from surface waters/ river & 0.31 \\
\hline & & Ground waters & 0.31 \\
\hline & & Distance from key biodiversity/ protected areas & 0.05 \\
\hline & & Land cover & 0.05 \\
\hline & & Erosion Susceptibility & 0.12 \\
\hline & & Soil permeability & 0.16 \\
\hline \multirow[t]{3}{*}{ Physical } & \multirow[t]{3}{*}{0.24} & Distance from built-up areas/settlements & 0.68 \\
\hline & & Distance from cultural heritage & 0.22 \\
\hline & & Distance to Faults (Seismic Conditions) & 0.10 \\
\hline
\end{tabular}

Source: Kara \&Doratli, 2012

\section{E. GIS Process}

The study utilized ArcGIS ${ }^{\mathrm{TM}}$, licensed to UP Los Baños, to develop the Landfill Suitability Model for Landfill Site Selection of the Ifugao Province, Philippines.

\section{Data Preparation}

Initially, the study prepared the input geospatial data through the process of clipping and conversion. Clipping was performed by overlaying the area of interest on the input maps (larger extent) and extracting only the target feature data within the area outlined by the clip polygon. On the other hand, conversion which is the process of converting one data format to another, in this case feature class to raster, was executed because most of the input open source data are in feature class format but raster format is required to perform the suitability model.

\section{Data Analysis}

Three types of spatial analyses were conducted in order to produce the data requirements of the suitability model. First is the slope map generation. This process was executed by running the slope command under the surface tool of the spatial analysis toolbox. The slope was classified according to DAO classification, wherein there is consideration for mountainous areas such as Ifugao. Second is the Euclidean distance. Out of 12 
criteria, six layers were subjected to Euclidean distance (ArcGIS toolbox > Spatial Analysis > Distance > Euclidean distance). These layers include distance from road, distance from inland waters, distance from environmentally sensitive areas, distance from settlements, distance from cultural sites and distance from faults. This tool was used to calculate the distance closest to the source and to create zones with varying influence from the center. Specifically, this was used to calculate the easement in compliance with the DENR guidelines in determining suitable sanitary landfill sites.

And third is the Reclassification tool. This process (ArcGIS toolbox > Spatial Analysis > Reclass > Reclassify) changes the values based on the defined or operationally set classification of zones. The tool reclassifies the zones created in Euclidean distance and slope analyses based on the sub-criterion zones provided by both literatures and laws. These layers include distance from the road, distance from surface waters/rivers, distance from environmentally sensitive areas, distance from settlements, distance from cultural sites, distance from faults and slopes. These were reclassified into restricted, very low suitability, low suitability, moderate suitability, high suitability and very high suitability based on the sub-criterion zones.

\section{Suitability Modeling}

Suitability modeling was performed using the weighted overlay analysis tool (ArcGIS toolbox > Spatial Analysis > Overlay > Weighted Overlay). It is defined as a tool that overlay several rasters using a common measurement scale and weights each according to its importance (ArcGIS Help). There are two levels of weighted overlay that were executed. First level, there were individual overlay for the three main criteria namely: economic, environmental and physical. In this part, each main criterion was executed overlay individually. Second level, there was an overlay for the combination of three main criteria. Overall, there were four overlay analysis executed. In terms of weights, each layer/sub criterion for each main criterion as well as the three main criteria has respective weights (see Table 3).

\section{RESULTS AND DISCUSSION}

\section{A. Criterion: Economic}

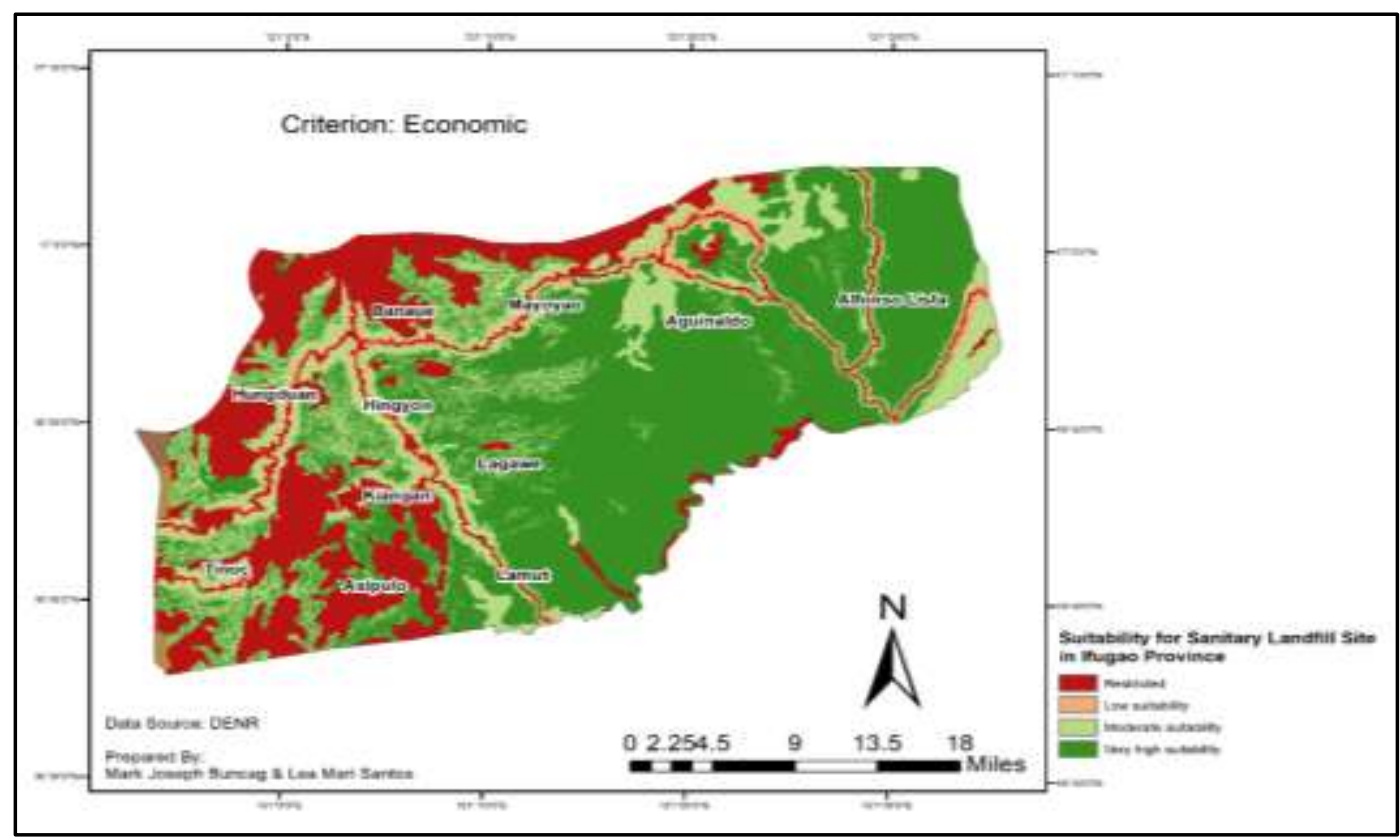

Figure 3. Map Overlay for Economic Criterion

Figure 3 shows the result map for the weighted overlay for Economic criterion which consist of land use, slope and road layers. This criterion has a weight of $21 \%$ as degree of influence in identifying the suitable sanitary landfill site/s. Based from the map there are areas fall on restricted, low, moderate and very high 
suitability for sanitary landfill site using layers under economic criterion in which large areas in Alfonso Lista, Aguinaldo, Lagawe and Lamut fall on very high suitability.

\section{B. Criterion: Environment}

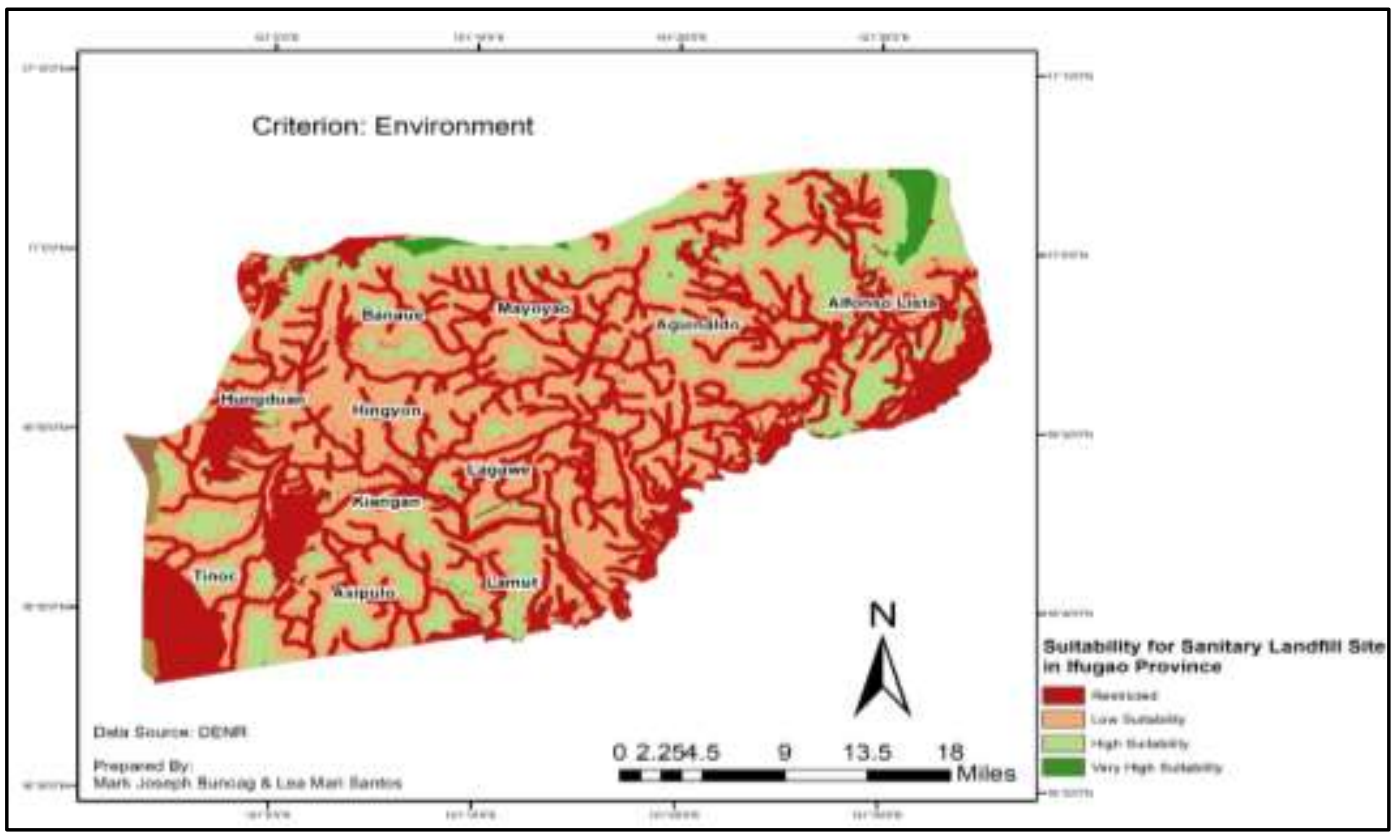

Figure 4. Map Overlay for Environmental Criterion

Figure4shows the result map for the weighted overlay for Environment criterion which consist of river, ground water, key biodiversity/protected area, land cover, soil erosion and soil layers. This criterion has a weight of 55\% as degree of influence in identifying the suitable sanitary landfill site/s. Based from the map there are areas fall on restricted, low, high and very high suitability for sanitary landfill site using layers under economic criterion in which large areas in all municipalities restricted and low suitability. Alfonso Lista is the municipality with the highest area that fall on very high suitability.

\section{Criterion: Physical}

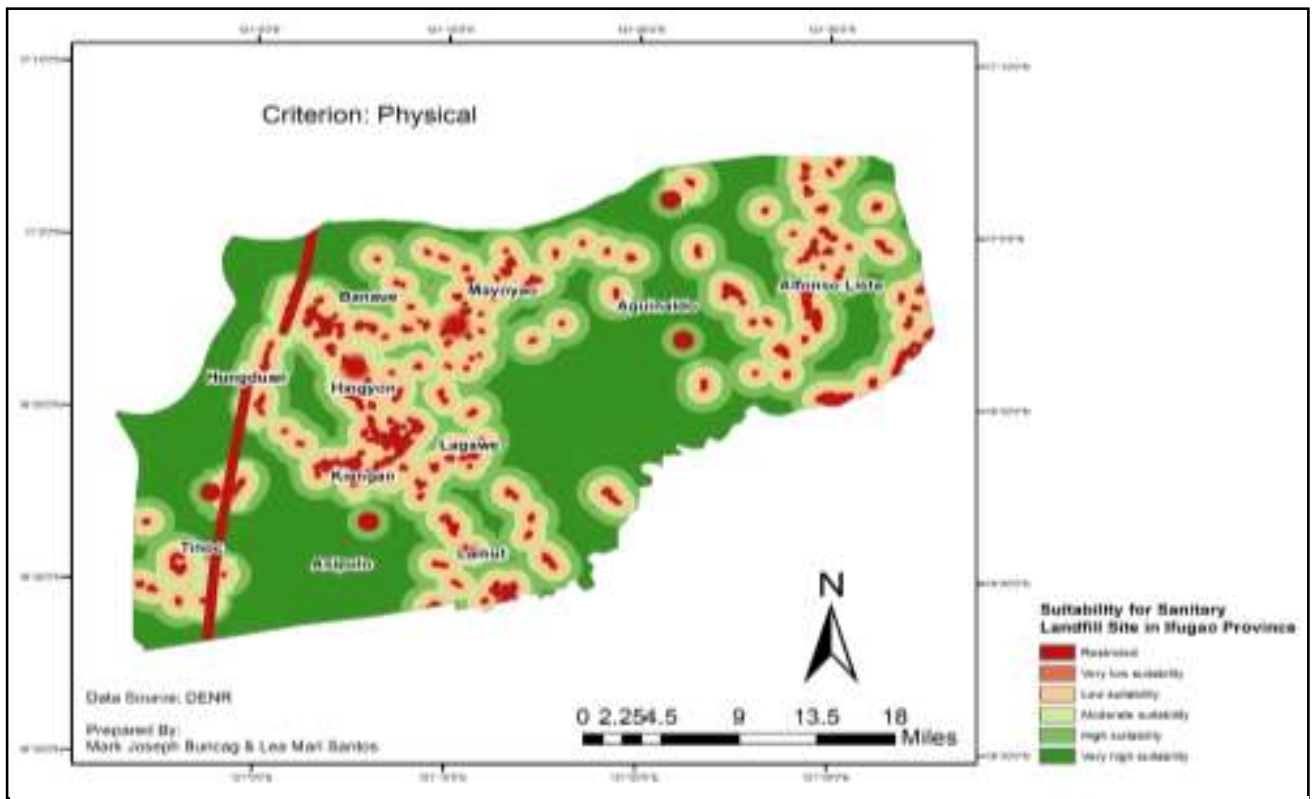

Figure 5. Map Overlay for Physical Criterion 
Figure 5shows the result map for the weighted overlay for Physical criterion which consist of built-up area, cultural sites, and faults layers. This criterion has a weight of $24 \%$ as degree of influence in identifying the suitable sanitary landfill site/s. Based from the map there are areas fall on restricted, very low, low, moderate, high and very high suitability for sanitary landfill site using layers under economic criterion in which large areas fall on high and very high suitability. All municipalities have some areas fall in restricted zone.

\section{Landfill Site Suitability by Municipality}

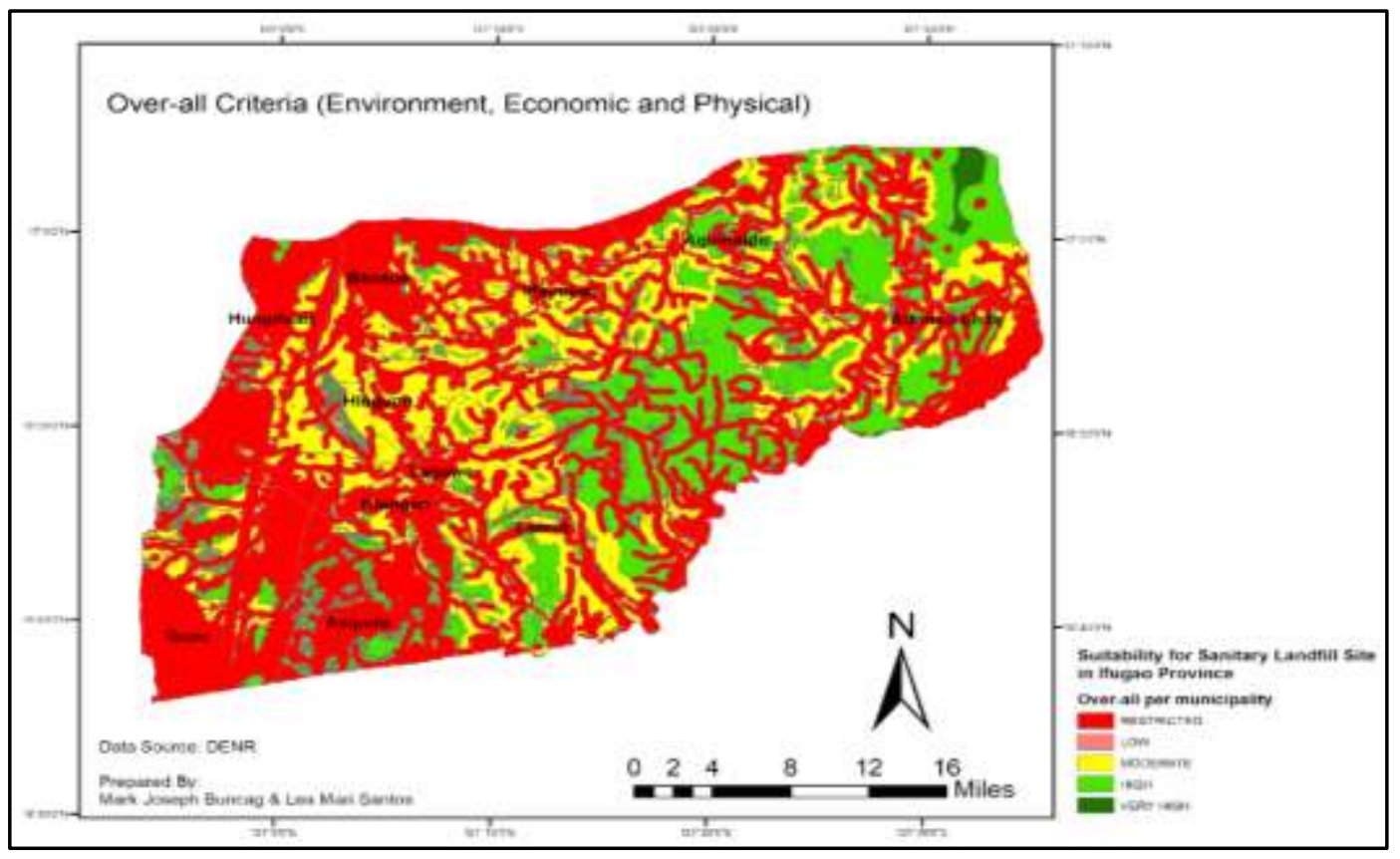

Figure 6. Landfill Site Suitability Map by municipality

Figure 6 shows the result map for the weighted overlay for the combination of three criteria namely: Economic, Environment and Physical with the weight of 21\%, 55\% and 24\% respectively. Based from the map there are areas fall on restricted, low, moderate, high and very high suitability for sanitary landfill site using layers under economic criterion in which large areas of Ifugao province fall on restricted zone. Only Municipality of Alfonso Lista has areas fall on very high suitability and with the largest area fall on high suitability. Based from the result of analysis, the sanitary landfill site in Ifugao is highly suitable in Alfonso Lista (see Table 4).

Table 4. Suitable Areas per Municipality

\begin{tabular}{|l|c|c|c|}
\hline \multirow{2}{*}{ MUNICIPALITY } & \multicolumn{3}{|c|}{ SUITABILITY (area in ha) } \\
\cline { 2 - 4 } & Moderate & High & Very high \\
\hline Aguinaldo & 9,121 & 11,907 & $\mathbf{1 , 2 8 7}$ \\
\hline Alfonso Lista & 9,737 & 14,232 & 0 \\
\hline Asipulo & 1,592 & 3,465 & 0 \\
\hline Banaue & 5,234 & 561 & 0 \\
\hline Hingyon & 3,689 & 203 & 0 \\
\hline
\end{tabular}




\begin{tabular}{|l|c|c|c|}
\hline Hungduan & 5,036 & 1,092 & 2 \\
\hline Kiangan & 2,445 & 389 & 0 \\
\hline Lagawe & 9,160 & 5,817 & 0 \\
\hline Lamut & 4,896 & 2,907 & 0 \\
\hline Mayoyao & 6,271 & 5,120 & 0 \\
\hline Tinoc & 3,260 & 2,464 & 0 \\
\hline
\end{tabular}

Table 4 shows the suitable areas (in ha) per municipality of Ifugao. Only three municipalities have areas that fall under the category of very high suitability, namely Alfonso Lista (1,287 ha), Aguinaldo (9 ha), and Hungduan ( 2 ha). All municipalities have areas under the category high and moderate suitability. Top 3 municipalities for highsuitability are Alfonso Lista (14, 232 ha), Aguinaldo (11, 907 ha), and Lagawe (5, 817 ha). Top 3 municipalities for moderate suitability are Alfonso Lista (9,737 ha), Aguinaldo (9,121 ha), and Lagawe $(9,160$ ha).

Figure6 shows the result map for the weighted overlay for the combination of three criteria namely: Economic, Environment and Physical. Only Municipality of Alfonso Lista has areas fall on very high suitability and with the largest area fall on high suitability. Based from the result of analysis, the sanitary landfill site in Ifugao is highly suitable in Alfonso Lista specifically in the following barangays: Kiling, Caragasaan and Little Tadlian (see Table 5).

\section{E. Landfill Site Suitability by Barangay}

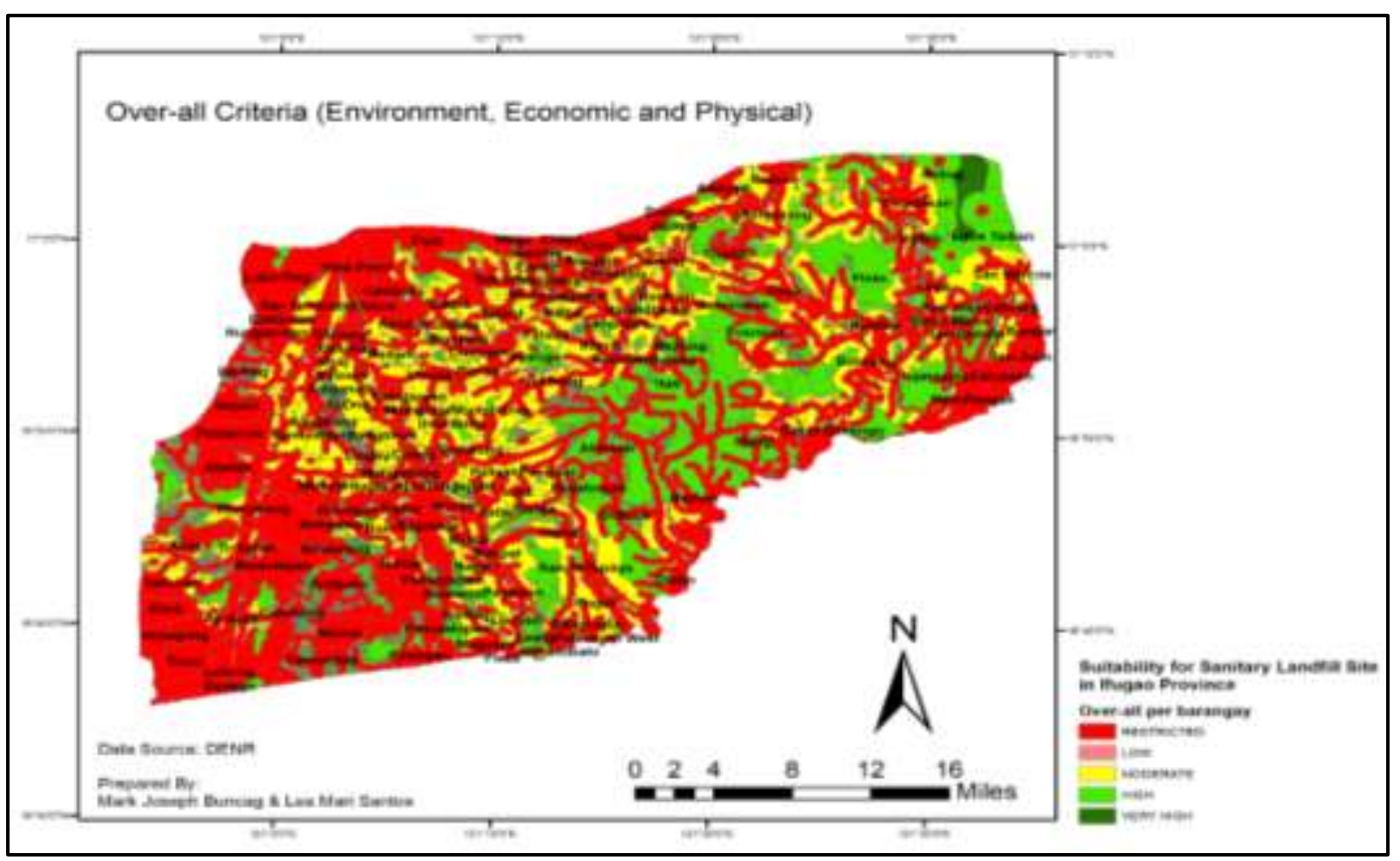

Figure 7. Landfill Site Suitability Map by barangay 
Table 5. Suitable Areas per Barangay (Top Barangays)

\begin{tabular}{|l|c|c|c|}
\hline \multirow{2}{*}{ BARANGAY } & \multicolumn{3}{|c|}{ SUITABILITY (area in ha) } \\
\cline { 2 - 4 } & Moderate & High & Very High \\
\hline Caragasan & 1,578 & 2,064 & 335 \\
\hline Damag & 472 & 570 & 9 \\
\hline Halag & 293 & 2,505 & 0 \\
\hline Kiling & 856 & 2,077 & $\mathbf{6 9 7}$ \\
\hline Little Tadian & 219 & 1,230 & 224 \\
\hline Lubo-Ong & 475 & 216 & 0 \\
\hline Nattum & 299 & 3,653 & 0 \\
\hline Pinto & 700 & 2,547 & 0 \\
\hline Posnaan & 1,191 & 2,802 & 32 \\
\hline Santo Domingo & 824 & 1,776 & 2 \\
\hline
\end{tabular}

Table 5 shows the suitable areas (in ha) per barangay of Ifugao. Only five barangays have areas that fall under the category of very high suitability, top 3 barangays for very high suitability areKiling (697 ha), Caragasan (335 ha), Little Tadian (224 ha).

All barangays have areas under the category high and moderate suitability. Top 3 barangays for high suitability are Nattum (3,653 ha), Posnaan (2,802 ha), and Halag (2,505 ha). Top 3 barangays for moderate suitability are Posnaan (1,192 ha), Caragasan (1,578 ha), and Kiling (856 ha).

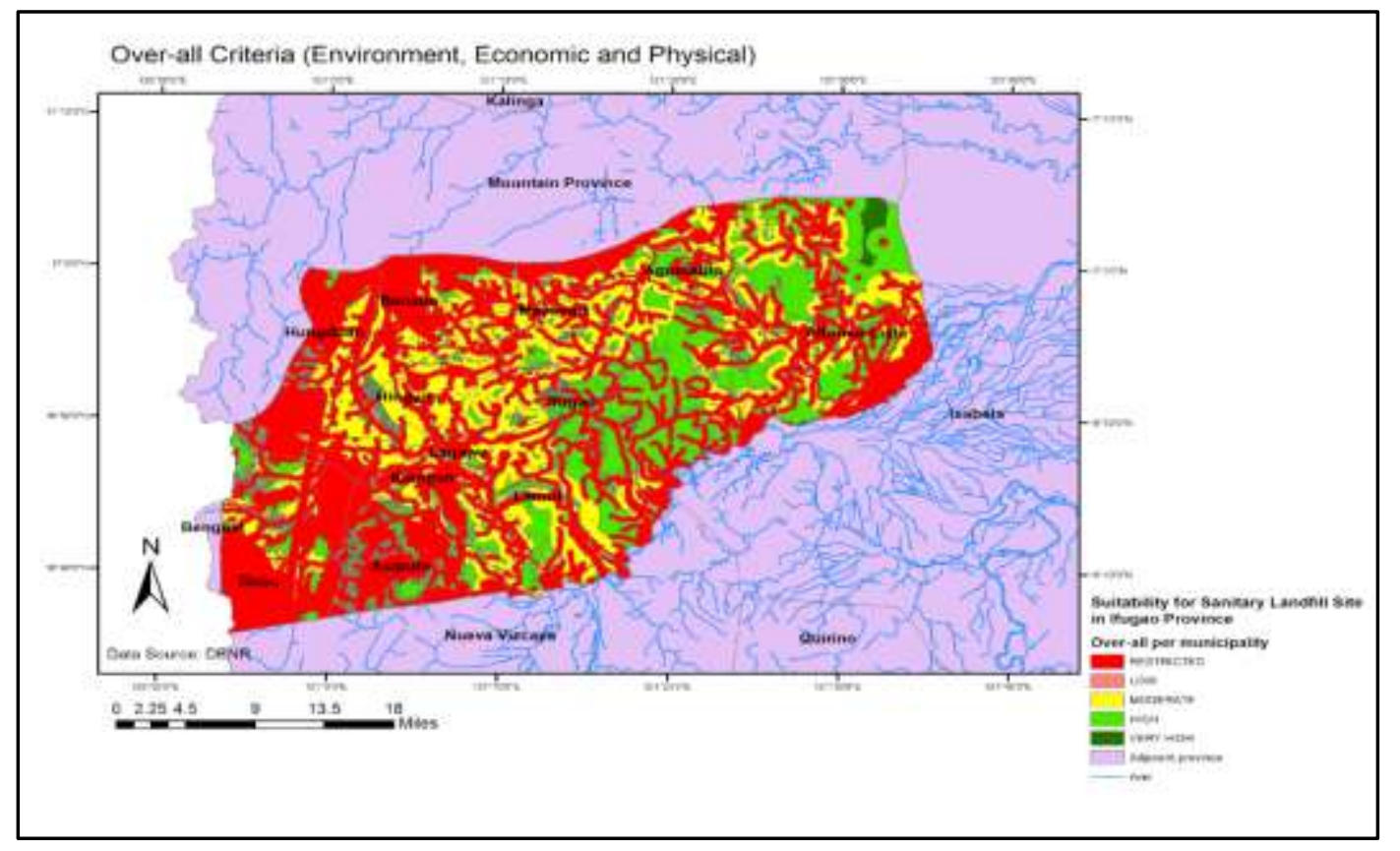

Figure 8. Landfill Site Suitability Map considering River Systems 
Figure8shows the river system of the adjacent provinces like Mountain Province, Isabela, Nueva Viscaya and Benguet. This shows that most of the areas along the boundaries of Ifugao and other provinces fall on restricted areas. However, the are some areas fall on very high and high suitability like in the case of Alfonso Lista. Some barangays in Alfonso Lista particularly in Kiling, Caragasaan and Little Tadlian are far from the river system in the adjacent provinces like Isabela. In this case, it is highly suitable for establishing sanitary landfill.

In addition, data availability serves as a major challenge in conducting this study. Specifically, the availability of some layers that can be used for deeper and more comprehensive analysis.

\section{CONCLUSION}

Based from the result of analysis, municipality of Ifugao Lista is the municipality with the largest areas that fall on very high suitability for sanitary landfill site. Specifically, this very suitable areas can be located in Barangays Kiling, Caragasaan and Little Tadlian. In terms of total area that fall on very suitable in Barangays Kiling, Caragasaan and Little Tadlian are 696.9 has, 334.8 has, and 223.6 has respectively. In addition, the computed total land area requirement needed for Ifugao considering the population, wastes generation, wastes density, height and residence time is 16.77 hectares.

\section{RECOMMENDATIONS}

1) Prioritize the areas that are very highly suitable site/s for the establishment of sanitary landfill in Ifugao province;

2) Conduct full Environmental Impact Assessment to identify, quantity and predict socio-economic and environmental Impacts. With this, negative impacts can be mitigated, and positive impacts can be enhanced;

3) Comply the requirements and guideline provided by RA 9003 otherwise known as Ecological Solid Wastes Management Act of 2001 in establishing sanitary landfill particularly on: liners, leachate collection and treatment system, gas control recovery system, groundwater monitoring well system, cover, closure procedure and post-closure care procedure

4) Conduct wastes characterization or assessment. Based on wastes characterization/assessment, create policies, incentive-based approach, market other appropriate approach.

5) Provide seminars/trainings/IEC on: a.) wastes minimization/avoidance b.) 3Rs c.) wastes to livelihood. In addition, provide other needed supports needed by the community for wastes management

6) Provide strategies: Sanitary landfill is intended only for wastes needed treatment and management (e.g. residuals). Recyclable must be recycled, and Biodegradable must be managed by every household/community (e.g. use as fertilizers, decompose using biodigester etc.)

\section{REFERENCES}

[1] Department of Environment and Natural Resources (1998). Department Administrative Order No. 50 Series of 1998. Adopting the Landfill Site Identification and Screening Criteria For Municipal Solid Waste Disposal Facilities

[2] Kara, C., \&Doratli, N. (2012). Application of GIS/AHP in siting sanitary landfill: A case study in Northern Cyprus. Waste Management and Research, 30(9), 966-980. https://doi.org/10.1177/0734242X12453975

[3] National Solid Wastes Management Council (2015). National Solid Waste Management Commission National Solid Waste Management Status Report (2008-2014). Republic of the Philippines Department of Environment and Natural Resources Environmental Management Bureau.

[4] Retrieved from http://nswmc.emb.gov.ph/wp-content/uploads/2016/06/Solid-Wastefinaldraft-12.29.15.pdf

[5] National Solid Wastes Management Council (2013). Resolution No. 64 series of 2013: Adoption of Modified Guidelines on Site Identification Criteria and Suitability Assessment Procedure for Sanitary Landfill.

[6] Senate Economic Planning Office (2017). Philippine Solid Wastes, (9003). Senate of the Philippines. Retrieved from https://www.senate.gov.ph/publications/SEPO/AAG_Philippine Solid Wastes_Nov2017.pdf 